\title{
Adhesion Properties of Lactobacillus plantarum Dad-13 and Lactobacillus plantarum Mut-7 on Sprague Dawley Rat Intestine
}

\author{
Arum Darmastuti ${ }^{1}\left(\mathbb{D}\right.$, Pratama N. Hasan ${ }^{2,3}$, Rachma Wikandari ${ }^{1,2}$, Tyas Utami ${ }^{1,2,3}$, Endang S. Rahayu ${ }^{1,2,3, *(D)}$ \\ and Dian Anggraini Suroto 1,2,3,*(D)
}

1 Faculty of Agricultural Technology, Universitas Gadjah Mada, Flora Street No 1 Bulaksumur, Yogyakarta 55281, Indonesia; arum.darmastuti@mail.ugm.ac.id (A.D.); rachma_wikandari@mail.ugm.ac.id (R.W.); tyas_utami@ugm.ac.id (T.U.)

2 Center for Food and Nutrition Studies, Universitas Gadjah Mada, Yogyakarta 55281, Indonesia; pratama.nur.h@mail.ugm.ac.id

3 University Center of Excellence for Research and Application on Integrated Probiotic Industry, Universitas Gadjah Mada, Yogyakarta 55281, Indonesia

* Correspondence: endangsrahayu@ugm.ac.id (E.S.R.); diananggrainisuroto@ugm.ac.id (D.A.S.)

check for updates

Citation: Darmastuti, A.; Hasan, P.N.; Wikandari, R.; Utami, T.; Rahayu, E.S.; Suroto, D.A. Adhesion Properties of Lactobacillus plantarum Dad-13 and Lactobacillus plantarum Mut-7 on Sprague Dawley Rat Intestine. Microorganisms 2021, 9, 2336. https://doi.org/10.3390/

microorganisms 9112336

Academic Editor: Stefan Junne

Received: 16 September 2021

Accepted: 8 November 2021

Published: 11 November 2021

Publisher's Note: MDPI stays neutral with regard to jurisdictional claims in published maps and institutional affiliations.

Copyright: (c) 2021 by the authors. Licensee MDPI, Basel, Switzerland. This article is an open access article distributed under the terms and conditions of the Creative Commons Attribution (CC BY) license (https:// creativecommons.org/licenses/by/ $4.0 /)$.

\begin{abstract}
Adhesion capacity is considered one of the selection criteria for probiotic strains. The purpose of this study was to determine the adhesion properties of two candidate probiotics, Lactobacillus plantarum Dad-13 and Lactobacillus plantarum Mut-7. The evaluation included the hydrophobicity of the cell surface using microbial adhesion to hydrocarbons (MATH), autoaggregation, and the adhesion of L. plantarum Dad-13 and L. plantarum Mut-7 to the intestinal mucosa of Sprague Dawley rat, followed by genomic analysis of the two L. plantarum strains. L. plantarum Dad-13 and L. plantarum Mut-7 showed a high surface hydrophobicity $(78.9 \%$ and $83.5 \%)$ and medium autoaggregation ability ( $40.9 \%$ and $57.5 \%$, respectively). The exposure of both isolates to the surface of the rat intestine increased the total number of lactic acid bacteria on the colon compartment, from $2.9 \log \mathrm{CFU} / \mathrm{cm}^{2}$ to $4.4 \log \mathrm{CFU} / \mathrm{cm}^{2}$ in L. plantarum Dad-13 treatment and to $3.86 \mathrm{log} \mathrm{CFU} / \mathrm{cm}^{2}$ in L. plantarum Mut-7 treatment. The results indicate the ability of two L. plantarum to attach to the surface of the rat intestine. The number of indigenous E. coli in the colon also decreased when the compartment was exposed to L. plantarum Dad-13 and Mut-7, from $2.9 \log \mathrm{CFU} / \mathrm{cm}^{2}$ to $1 \log$ $\mathrm{CFU} / \mathrm{cm}^{2}$. Genomic analysis revealed that both strains have genes related to adhesion properties that could play an important role in increasing the adherence of probiotics to the intestinal mucosa such as gene encoding fibronectin-binding protein, chaperonin heat shock protein 33 (Hsp33), and genes related to the capsule and cell wall biosynthesis. Based on these findings, we believe that L. plantarum Dad-13 and L. plantarum Mut-7 have adhesion properties to the intestinal mucosa in the rat intestine model system. The present research will be essential to elucidate the molecular mechanism associated with adhesion in our two probiotic strains.
\end{abstract}

Keywords: probiotic; Lactobacillus plantarum; hydrophobicity; autoaggregation; adhesion ability

\section{Introduction}

Probiotics are living microorganisms that, when consumed in sufficient quantities, can provide health benefits [1]. Most probiotic bacteria are lactic acid bacteria (LAB), such as Lactobacillus species, Lactobacillus casei, L. paracasei, and L. rhamnosus. L. plantarum are the most common probiotic bacteria, representing a potential group of microbes, and have been widely used in various fermented food products [2]. Fermented foods that contain LAB can provide benefits in terms of bodily health when properly consumed. These beneficial effects are associated with the balance of the healthy gut microbiota, as well as the prevention of diarrhea, reduction in cholesterol, regulation of lactose intolerance, and gastrointestinal 
comfort [3]. Nowadays, products of lactic acid bacteria have been widely applied in the food industry in dairy products, vegetables, meat, wine, etc. [4].

Lactic acid bacteria that can be categorized as probiotics must have several crucial features, including resistance to gastric fluids (low $\mathrm{pH}$ ), resistance to bile salts, good ability to live in the digestive tract, ability to attach to the intestinal mucosa, and antimicrobial activity against pathogens $[3,5]$. According to Okochi et al [6], the ability of LAB to attach to the intestinal mucosa can increase the survival rate of $\mathrm{LAB}$ in the gastrointestinal tract and enable probiotics to grow. Good adhesion capabilities can protect the intestinal mucosa from pathogenic bacteria [7]. The adhesion properties of LAB are associated with the properties and ability of bacteria to aggregate [8].

The bacterial adhesion mechanism on the gastrointestinal surface involves a nonspecific hydrophobic group interaction and a specific adhesion-receptor interaction. Nonspecific and reversible interactions could occur through involving physicochemical interaction, such as the surface hydrophobicity of LAB cells [9]. On the other hand, specific and irreversible interactions could occur through mediating adhesins, one of the proteins found on the surface of LAB cells, which help the colonization process of the bacterial cell surfaces and involve complementary receptors on host cells [10].

Probiotics capable of forming colonies in the intestinal tract are needed to improve the balance of intestinal microflora [11]. Probiotics must have the ability to adhere to the intestinal cell to increase their chance of survival in the gastrointestinal tract $[6,12]$. Some probiotic strains can inhibit the adherence of pathogenic bacteria to the intestinal mucosa either by forming a barrier via autoaggregation or by direct coaggregation with the pathogens [13-15]. Lactobacilli that have a high autoaggregation ability show a high hydrophobicity $[16,17]$. It was also reported that the proteins, glycoproteins, and teichoic and lipoteichoic acids on the cell wall surface of bacteria play important roles in the autoaggregation and hydrophobicity of the various strains [18].

Autoaggregation and the hydrophobic properties of the cell surface have been associated with adhesion. To achieve the desired benefits of probiotic bacteria, they must form a sufficiently large biomass through aggregation [19]. A previous study by Nuraida et al. [20] mentioned that the positive hydrophobicity result of LAB indicated its hydrophobic properties. These hydrophobic properties indicate that it may be easier for LAB to attach to the gastrointestinal tract. Microbial adhesion to hydrocarbons (MATH) is the common method that is used to measure the hydrophobicity properties of the surface of lactic acid bacteria. Hydrophobicity is evaluated as the affinity of microorganisms to a solvent, such as hexane, xylene, or toluene [19]. When probiotics adhere to the epithelium, they can function stably in the intestine. Therefore, probiotic functions can be beneficial to the gut and health [21]. As mentioned by Ferreira et al. [15], the autoaggregation ability plays an important role in cell adherence properties, involving the ability of cells to form colonies, which can therefore affect their ability to survive and persist in the gastrointestinal tract. Generally, autoaggregation (\%) is classified into three groups: high autoaggregation $(>70 \%)$, medium autoaggregation (20-70\%), and low autoaggregation $(<20 \%)$ [22]. Both hydrophobicity and autoaggregation are necessary in order for the probiotic to bind better to epithelial cells and thus colonize the gastrointestinal tract [23].

Our laboratory has successfully isolated and characterized indigenous probiotic strains-namely Lactobacillus plantarum Dad-13 and Lactobacillus plantarum Mut-7. Lactobacillus plantarum Dad-13 was isolated from fermented buffalo milk (Dadih) in the West Sumatra region, while Lactobacillus plantarum Mut-7 was isolated from fermented dried cassava (Gatot) [24]. Both LABs have potential as good probiotics because they can survive at acidic $\mathrm{pHs}(\mathrm{pH} 2)$, are resistant to bile salts at levels of up to $3 \%$, and can inhibit pathogenic bacteria such as Shigella dysenteriae dky-4, E. coli ST, and E. coli OK111. However, the adhesion properties of L. plantarum Dad-13 and L. plantarum Mut-7 have not yet been established.

The adhesion capability of LAB on the surface of the mucosa is necessary in order for $\mathrm{LAB}$ to form colonies in the digestive tract so that it can function as a probiotic [25]. 
The adhesion ability of LAB can be affected by hydrophobicity and the ability of bacteria to aggregate (autoaggregation) [21]. LABs with hydrophobic surface properties find it easier to attach to the intestinal tract. Moreover, lactic acid bacteria that can form aggregates or colonies of the same strain could possibly facilitate the adhesion process in the gastrointestinal tract [26].

In the present study, our objective was to investigate the adhesion properties of Lactobacillus plantarum Dad-13 and L. plantarum Mut-7 in the rat intestine and identify genes that play a role in the adhesion of LAB in the intestinal tract.

\section{Materials and Methods}

\subsection{Microorganism and Culture Preparation}

This study used 2 isolates of lactic acid bacteria-namely, Lactobacillus plantarum Dad13 (isolated from curd, fermented buffalo milk) and L. plantarum Mut-7 (isolated from gatot, fermented cassava) - which were obtained from the Food and Nutrition Culture Collection (FNCC), Center for Food and Nutrition Studies, Universitas Gadjah Mada.

\subsection{Preparation of Bacterial Culture}

Lactic acid bacteria were grown in MRS (de Man, Rogosa and Sharpe, Merck, Darmstadt, Germany) and incubated at a temperature of $37^{\circ} \mathrm{C}$ for $24 \mathrm{~h}$ before their use.

\subsection{The Cell Surface Hydrophobicity Assays of LAB}

The method used for testing the properties of $\mathrm{LAB}$ cell surfaces was microbial adhesion to hydrocarbons (MATH) [19]. The principle of this method is to measure the affinity of the suspension against xylene, which is used as a hydrocarbon solvent. The strain was grown in MRS broth for $18 \mathrm{~h}$ at a temperature of $37^{\circ} \mathrm{C}$, then centrifuged. The medium was removed and the cells were washed twice with a buffer solution of magnesium sulfate phosphate (PUM) (composition (g/L): $\mathrm{K}_{2} \mathrm{HPO}_{4} \cdot 3 \mathrm{H}_{2} \mathrm{O}: 22.2, \mathrm{KH}_{2} \mathrm{PO}_{4}$ : 7.26. urea: $1.8, \mathrm{MgSO}_{4} \cdot 7 \mathrm{H}_{2} \mathrm{O}$ : $0.2, \mathrm{pH}$ 7.1). The suspension of bacteria formed and then the absorption was measured using a spectrophotometer (Genesys 150, Thermoscientific, Waltham, MA, USA) with a wavelength of $600 \mathrm{~nm}$. A total of $5 \mathrm{~mL}$ of bacterial suspension was mixed with $1 \mathrm{~mL}$ of xylene. The mixture was incubated at $37^{\circ} \mathrm{C}$ for $1 \mathrm{~h}$. The final absorbance measurement was carried out with a wavelength of $600 \mathrm{~nm}$. The suspension affinity against xylene was measured using the following formula:

$$
\text { Surface hydrophobicity }(\%)=\mathrm{A}_{0}-\mathrm{A} / \mathrm{A}_{0} \times 100 \% \text {. }
$$

Description:

$\mathrm{A}_{0}$ : OD value of $600 \mathrm{~nm}$ initial suspension;

A: OD value of $600 \mathrm{~nm}$ suspension after mixed hydrocarbons.

\subsection{LAB Autoaggregation Properties Assays}

Autoaggregation assays were performed according to Nuraidaetal [20]. The strain was grown in MRS broth for $18 \mathrm{~h}$ at a temperature of $37^{\circ} \mathrm{C}$ and then centrifuged. The medium was removed and the cells were washed with phosphate-buffered saline (PBS) twice. The suspension of bacteria formed and the absorption were measured using a spectrophotometer (Genesys 150, Thermoscientific) with a wavelength of $600 \mathrm{~nm}$. The suspension was measured at the 0 and 5 th hours. The suspension was incubated for $5 \mathrm{~h}$ at a temperature of $37^{\circ} \mathrm{C}$. Absorbance measurement was carried out by taking a suspension of $1 \mathrm{~mL}$ and adding it to $3.9 \mathrm{~mL}$ of PBS solution.

The percentages of autoaggregation properties were calculated using the formulas:

$$
\text { Autoaggregation }(\%)=1-(\mathrm{At} / \mathrm{A} 0) \times 100
$$

Description: 
At $=$ absorbance at $\mathrm{t}=5 \mathrm{~h}$;

$\mathrm{A} 0=$ absorbance at $\mathrm{t}=0 \mathrm{~h}$.

\subsection{LAB Adhesion Properties Assays on the Rat Intestine}

The adhesion properties of two lactobacilli were determined using the method of Nuraida et al [20] with some modifications. LAB isolates were grown in MRS broth for $24 \mathrm{~h}$ and then centrifuged at $3500 \mathrm{rpm}$ for $15 \mathrm{~min}$. The cell pellet formed was washed with PBS and resuspended with PBS until a level of $10^{6} \mathrm{CFU} / \mathrm{mL}$ was reached. Two compartments of 8-week-old Sprague Dawley rat intestines were used-i.e., the ileum and the colon. The ileum and colon compartments were cut at about $5 \mathrm{~cm}$, opened, and rinsed using a phosphate buffer solution (PBS). A piece of rat intestine was placed in a Petri dish and $10 \mathrm{~mL}$ of LAB isolate suspension was added. The Petri dish was incubated at room temperature for $60 \mathrm{~min}$. At the end of the incubation, the rat intestine was removed and washed with PBS, then added to a sterile Petri dish. To measure the amount of $\mathrm{LAB}$ attached and the $E$. coli of the surface of the intestine, $1 \mathrm{~cm}^{2}$ of the intestine surface was swabbed using a sterile cotton bud. Cells in the cotton bud were suspended in $0.85 \% \mathrm{NaCl}$ solution and serial dilution was performed. The LAB from the cell suspension was enumerated using MRS agar, while Escherichia coli was enumerated using Brilliance E. coli/coliform selective medium. The tests were carried out twice.

\subsection{Genome Sequencing and Analysis}

The genome sequencing of the 2 Lactobacillus strains was carried out using the Illumina NovaSeq 6000 sequencing platform. The genome sequence analysis of L. plantarum Dad-13 and L. plantarum Mut-7 isolates was performed using rapid annotation in the Subsystem Technology (RAST) V2.0 software online.

\subsection{Statistical Analysis}

The data were analyzed using IBM SPSS Statistics version 20. The triplicate results of cell surface hydrophobicity and autoaggregation assays were analyzed using t-tests. The intestines of the two rats were used for testing the adhesion ability and the amount of indigenous Escherichia coli present, in which each test was performed twice. A one-way ANOVA followed by Duncan's test was performed to identify the difference in the results.

\section{Results and Discussion}

\subsection{Properties of Surface of LAB Cells}

The results of the tests of cell surface properties in the isolates L. plantarum Dad-13 and L. plantarum Mut-7 are shown in Table 1. According to the table below, both isolates had positive results for cell surface hydrophobicity.

Table 1. Hydrophobicity and autoaggregation (\%) of isolate strains.

\begin{tabular}{ccc}
\hline & \multicolumn{2}{c}{ Isolates Name } \\
\cline { 2 - 3 } & L. plantarum Dad-13 & L. plantarum Mut-7 \\
\hline Hydrophobicity (\%) & $78.9 \pm 5.9^{\mathrm{a}}$ & $83.5 \pm 5.7^{\mathrm{a}}$ \\
Autoaggregation (\%) & $40.9 \pm 2.1^{\mathrm{a}}$ & $57.5 \pm 5.5^{\mathrm{a}}$ \\
\hline
\end{tabular}

$\overline{\mathrm{a}, \mathrm{b}}$ Similar letters in the table indicate no significant difference, while different letters indicate a significant difference $(p<0.05)$.

In this study, xylene was used as the solvent. Having a low affinity (negative) for xylene indicates that the surface of bacterial cells is hydrophilic while having a high affinity (positive) for xylene indicates that bacterial cells are hydrophobic [20]. Gomaa et al. [27] reported that effective hydrophobicity was observed when xylene was used as a solvent in all the lactobacilli strains.

In the present study, the hydrophobicity of the cell surface of L. plantarum Dad-13 and L. plantarum Mut-7 was evaluated and both strains showed a variable degree of 
hydrophobicity around $78.9 \%$ and $83.5 \%$, respectively [28]. L. plantarum of six strains showed a good level of hydrophobicity and L. plantarum RYPR1 had the highest affinity for xylene (79.13\%) out of all the isolates. A previous study showed that several strains of L. plantarum had high hydrophobicity values $(>60 \%)$, with L. plantarum IFPL189, IFPL124, IFPL33, and IFPL207 having the highest affinities to xylene with values greater than $90 \%$ for the hydrophobicity of the cell surface [12]. A similar study by Handa et al. [29] reported that L. plantarum F22 had a high value of cell hydrophobicity of around $50.8 \%$.

Based on several studies, the hydrophobicity levels varied among the strains. The diversity of hydrophobicity based on the MATH method was caused by the influence of the variety of strains, the duration of the cultivation time, the cultivation medium used, the presence of acids, and the type of solvent used [19]. Hydrophobicity can differ between strains of species and changes with a change in the strain, suspension media composition, age of the bacteria, and structure of the cell surface [18]. The hydrophobicity of the probiotic cell surface increases when lactose is used as the sole carbon source [30]. On the contrary, the presence of elaidic acid could probably decrease the hydrophobicity level of lactobacilli [31].

The results of the autoaggregation properties of L. plantarum Dad-13 and L. plantarum Mut-7 isolates are shown in Table 1. Based on the test, it was found that the value of autoaggregation (\%) in the L. plantarum Dad-13 isolate was around $40.9 \%$ and that in L. plantarum Mut-7 was $57.5 \%$. The ability of autoaggregation enabled lactic acid bacteria to form aggregates and colonies that would be necessary for probiotic functions. This could allow one to attach and compete with the pathogenic bacteria that exist on the surface of the intestinal mucosa [12]. Both L. plantarum Dad-13 and L. plantarum Mut-7 are classified as having medium autoaggregation according to Rahman et al [22].

According to the results found by García-Cayuela et al. [12] for several varieties of Lactobacillus plantarum, selected Lactobacilli had high autoaggregation abilities of around 29.3-59.5\%. Another study carried out by Handa et al. [29] concluded that the autoaggregation percentage increased until the $5 \mathrm{~h}$ time point and in the final hour showed a high autoaggregation ability (79.5\%). Based on the results of Tuo et al. [21], no significant correlation was found between the cell surface hydrophobicity and autoaggregation among Lactobacilli strains.

\subsection{Properties of $L A B$ Adhesion to the Rat Intestine}

A test was used to determine the level of LAB that attached to the surface of the rat intestine and the results are shown in Table 2. The initial quantities of L. plantarum Dad-13 and L. plantarum Mut-7 isolates were $10^{6}-10^{7} \mathrm{CFU} / \mathrm{mL}$. Based on the results, L. plantarum Dad-13 and L. plantarum Mut-7 isolates were capable of attaching to the colon; however, neither attached in the ileum compartment.

Table 2. The number of LAB found after L. plantarum Dad-13 and L. plantarum Mut-7 were added with a 60 min incubation.

\begin{tabular}{cccc}
\hline \multirow{3}{*}{ Compartment } & \multicolumn{3}{c}{$\begin{array}{c}\text { Number of LAB } \\
\left(\mathbf{l o g} \text { CFU/cm }{ }^{2}\right)\end{array}$} \\
\cline { 2 - 4 } & PBS (No Addition of LAB) & L. plantarum Dad-13 & L. plantarum Mut-7 \\
\hline Ileum & $3.02 \pm 0.03^{\text {a }}$ & $3.5 \pm 0.4^{\text {a }}$ & $3.6 \pm 0.06^{\text {a }}$ \\
Colon & $2.9 \pm 0.08^{\text {a }}$ & $4.4 \pm 0.002^{\mathrm{b}}$ & $3.86 \pm 0.56^{\mathrm{b}}$ \\
\hline
\end{tabular}

$\overline{\mathrm{a}, \mathrm{b}}$ Similar small letters in the same row indicate no significant differences, while different letters indicate significant differences $(p<0.05)$.

According to Wang et al. [32] among several strains of Lactobacillus, most were able to adhere well to Caco- 2 and IEC- 6 cells. The highest capacity of adherence was observed with commercial L. acidophilus L050103, L. plantarum L2, L. plantarum L8, and L. plantarum L9. Previous studies concluded that among several strains of L. reuteri, L. casei, L. brevis, and $L$. paracasei, the results showed that all tested strains were able to adhere well to the 
mixed cell cultures of Caco-2 cells and mucus-secreting HT-29-MTX [19,33]. Furthermore, as shown by Nuraida et al. (2012), Lactobacillus sp. and L. rhamnosus had the ability to adhere to the surface of the rat intestine.

Several studies have tested the adhesion ability of probiotic strains; however, their findings are hardly comparable due to differences in the tissue model used. Different results from previous studies might occur due to the difference in the substrate used in the adhesion properties test. Substrate cells have different physicochemical and receptor properties that are influenced by the type of compound used, structure, and conformation [9].

The results of this study showed that L. plantarum Dad- 13 and L. plantarum Mut-7 were able to decrease the amount of indigenous E. coli in the colon (Table 3), which indicated that $\mathrm{LAB}$ was able to replace indigenous $E$. coli. The replacement of indigenous $E$. coli was probably caused by the attachment of L. plantarum Dad- 13 and L. plantarum Mut-7 to the colon, according to the results of Table 2. Furthermore, there was a significant difference in the number of indigenous E. coli in the ileum and colon compartments.

Table 3. The amount of indigenous E. coli present after L. plantarum Dad-13 and L. plantarum Mut-7 were added with 60 min of incubation.

\begin{tabular}{cccc}
\hline \multirow{2}{*}{ Comparison } & \multicolumn{3}{c}{$\begin{array}{c}\text { Number of Indigenous } \text { E. coli } \\
(\log \text { CFU/cm })^{2}\end{array}$} \\
\cline { 2 - 4 } & PBS (No Addition of LAB) & L. plantarum Dad-13 & L. plantarum Mut-7 \\
\hline Ileum & $2.9 \pm 0.15^{\mathrm{Aa}}$ & $2.42 \pm 0.73^{\mathrm{Aa}}$ & $2.54 \pm 0.48^{\mathrm{Aa}}$ \\
Colon & $2.9 \pm 0.52^{\mathrm{Ab}}$ & $1.0 \pm 0.00^{\mathrm{Ba}}$ & $1.0 \pm 0.00^{\mathrm{Ba}}$ \\
\hline
\end{tabular}

$\overline{\mathrm{A}, \mathrm{B}}$ Similar capital letters in the same column indicate that there are no significant differences, while different letters indicate significant differences $(p<0.05) .{ }^{a, b}$ Small letters in the same row indicate no significant differences, while different letters indicate significant differences $(p<0.05)$.

Two compartments of rat intestine were used in the present study: the ileum and colon. Although both compartments have superficial similarities, the ileum and colon have considerable differences in their physiology [34]. The thickness of the mucus layer tends to increase by about 30 to $300 \mu \mathrm{m}$ from the small intestine to the large intestine, and this might provide a more extensive mucosal habitat for lactic acid bacteria in the colon compared with the small intestine parts [35,36].

Some previous studies have shown that there was no correlation between the surface hydrophobicity of Lactobacillus and its ability to adhere to the intestinal mucosa [37-39]. However, some studies have reported a correlation between hydrophobicity and adhesion capacity. The higher the surface hydrophobicity value is, the higher the ability of bacterial cells to adhere to the intestinal mucosa is $[10,40]$.

The correlation between hydrophobicity and adhesion capability might occur because there are nonspecific interactions on the surface of the bacterial cells with the intestinal mucosa. The distance between the two surfaces of the bacterial cells and the intestinal mucosa causes an attractive force that is involved in hydrophobic interactions, resulting in reversible binding, and this is possible because the gastrointestinal mucosa is mostly hydrophobic due to the presence of mucus on its surface [9]. Although the detailed mechanism explaining the correlation between surface hydrophobicity of bacterial cells and adhesion to the intestinal mucosa is not clear, hydrophobicity and autoaggregation testing could be used as indicators in the initial screening to identify the potential adherence of lactic acid bacteria [10]. The present finding suggests that the adhesion ability test of the probiotic may provide important screening tools to determine the feasibility of lactic acid bacteria as probiotics.

\subsection{Genomic Analysis}

The results of genome annotations using RAST are shown in Figure 1a,b. Both figures showed the distribution of the subsystems in each isolate. In the bar chart, it appears that the $42 \%$ isolate coverage subsystem shows the entire subsystem working in physiological 
isolates. In the category of virulence, disease, and defense, the existence of subcategory adhesion includes the recombinatorial zone of Streptococcus. In this subsystem, it is evident that both isolates have gene specifications and functional functions, as shown in Table 4.

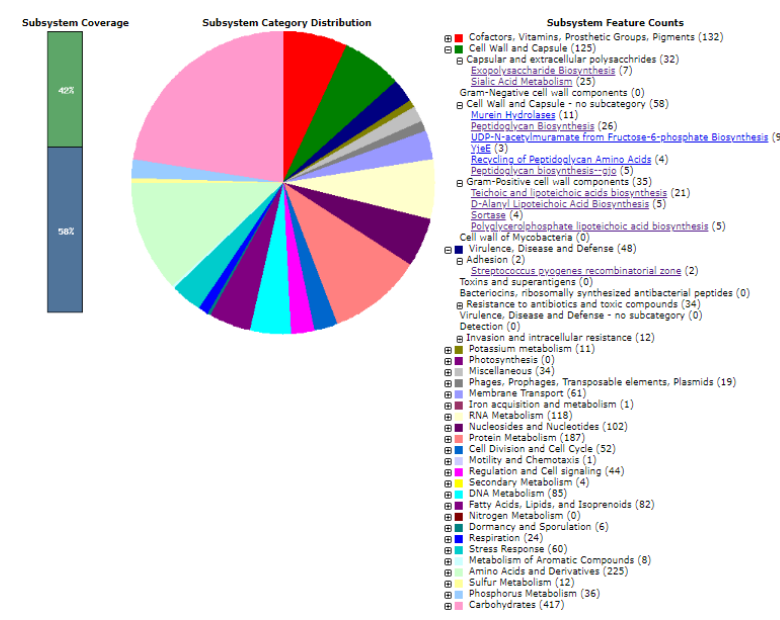

(a)

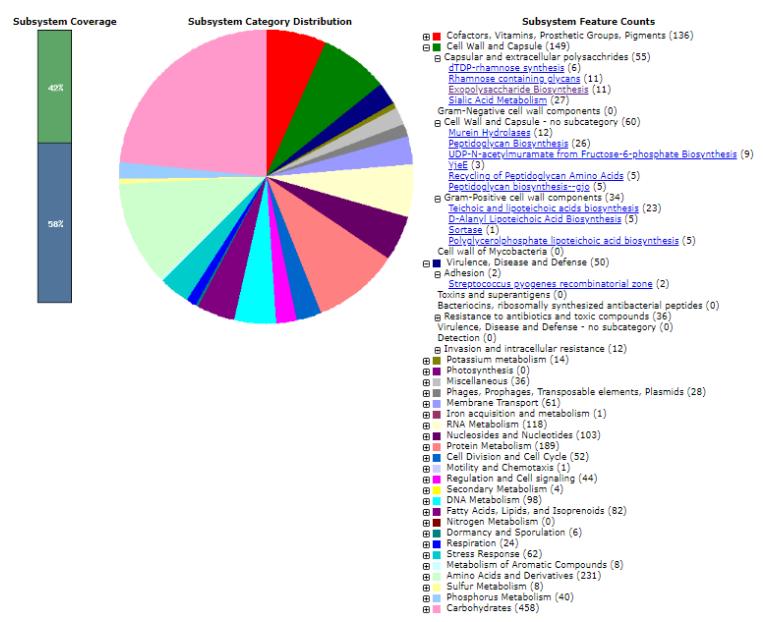

(b)

Figure 1. (a) Distribution of the L. plantarum Dad-13 subsystem of RAST annotation; (b) distribution of the L. plantarum Mut-7 subsystem of RAST annotation.

Table 4. Genes related to the adhesion of L. plantarum Dad-13 based on RAST.

\begin{tabular}{ccccccc}
\hline Category & Subcategory & Subsystem & Role & Abbreviations & Per. Identifier & Scientific Name \\
\hline $\begin{array}{c}\text { Virulence, } \\
\text { Disease, and } \\
\text { Defense }\end{array}$ & Adhesion & $\begin{array}{c}\text { Recombination } \\
\text { zone of } \\
\text { Streptococcus } \\
\text { pyogenes }\end{array}$ & $\begin{array}{c}\text { Fibronectin- } \\
\text { binding } \\
\text { protein }\end{array}$ & PtrF & $100 \%$ & Lactobacillaceae \\
\hline $\begin{array}{c}\text { Virulence, } \\
\text { Disease, and } \\
\text { Defense }\end{array}$ & Adhesion & $\begin{array}{c}\text { Recombination } \\
\text { zone of } \\
\text { Streptococcus } \\
\text { pyogenes }\end{array}$ & $\begin{array}{c}\text { Chaperonin (heat } \\
\text { shock protein 33) }\end{array}$ & hsp33 & $100 \%$ & Lactobacillaceae \\
\hline
\end{tabular}

L. plantarum Dad-13 and L. plantarum Mut-7 have important properties as probiotics, with genes that regulate adhesion and self-defense against antimicrobials. They contain genes that encode fibronectin-binding proteins ( $\mathrm{ptrF} /$ polymerase I and transcript release factor) and chaperonin (hsp33/heat shock protein 33), which regulate the adhesion of bacteria (Table 5).

Table 5. Genes related to the adhesion of L. plantarum Mut-7 based on RAST.

\begin{tabular}{|c|c|c|c|c|c|c|}
\hline Category & Subcategory & Subsystem & Role & Abbreviations & Per. Identifier & $\begin{array}{c}\text { Scientific } \\
\text { Name }\end{array}$ \\
\hline $\begin{array}{l}\text { Virulence, } \\
\text { Disease, and } \\
\text { Defense }\end{array}$ & Adhesion & $\begin{array}{l}\text { Recombination } \\
\text { zone of } \\
\text { Streptococcus } \\
\text { pyogenes }\end{array}$ & $\begin{array}{l}\text { Fibronectin- } \\
\text { binding } \\
\text { protein }\end{array}$ & PtrF & $100 \%$ & Lactobacillaceae \\
\hline $\begin{array}{l}\text { Virulence, } \\
\text { Disease, and } \\
\text { Defense }\end{array}$ & Adhesion & $\begin{array}{l}\text { Recombination } \\
\text { zone of } \\
\text { Streptococcus } \\
\text { pyogenes }\end{array}$ & $\begin{array}{l}\text { Chaperonin } \\
\text { (heat shock } \\
\text { protein 33) }\end{array}$ & hsp33 & $100 \%$ & Lactobacillaceae \\
\hline
\end{tabular}

The results of the genome annotations based on RAST showed the presence of genes related to the adhesion properties of $\mathrm{LAB}$-namely, polymerase I, transcript release fac- 
tor (ptrF), and heat shock protein 33 (hsp33). Both genes were known to have a 100\% identification to other species present in Lactobacillaceae based on the protein BLAST analysis. The PtrF gene encodes protein F, which is a bacterial surface protein that binds fibronectin at a high affinity. This gene produces a functional fibronectin-binding protein. The fibronectin-binding protein is a protein that can initiate the invasion process of microbes in the endothelium and is able to form a bridge between bacterial proteins that bind to fibronectin and host cell receptors [41,42].

Another gene that possibly plays a role in bacterial adhesion is hsp33. This gene is known as a new primary heat shock protein that has chaperone activity in addition to other variants such as hsp60, hsp70, hsp90, hsp100, and small heat shock proteins [43]. Hsp33 has been identified as a redox-sensitive chaperone that has functions in protecting unfolded proteins from aggregation in bacteria and is activated when oxidative stress and the unfolding condition coincide [44,45]. Furthermore, this heat shock protein could adhere to the host and microbial cell surface; therefore, it might be able to facilitate the easy attachment and colonization of bacteria [46]. In probiotic or lactic acid bacteria, attachment and colonization could be improved by the expression of a molecular chaperone such as heat shock protein and other co-chaperones [47]. However, the mechanism by which hsp33 contributes to adhesion to the cell host remains unclear.

Based on the RAST annotation, both L. plantarum Dad-13 and L. plantarum Mut-7 have no genes associated with hemolysin, lipids, and proteins that cause the lysis of red blood cells by disrupting the cell membrane, as one of the virulence factors. According to Rahayu et al. [48]), the consumption of L. plantarum Dad-13 does not negatively affect general health, organ weight, leukocyte profile, glutamic-oxaloacetic transaminase (GOT) activity, plasma malondialdehyde (MDA) concentration, or intestinal morphology in Sprague Dawley rats. Lactobacillus plantarum Dad-13 does not translocate in the organs and blood. Furthermore, Ikhsani et al. [49] reported that high-dose supplementation with L. plantarum Mut-7 does not have detrimental effects on general health, organ weight, hematology, and histological parameters in rats. Further, the bacterial translocation of L. plantarum Mut-7 was not detected in the blood or organs. Therefore, based on these findings, it was suggested that both probiotic bacteria are safe for consumption.

Previous studies conducted by Tropcheva et al. [50] on the adhesion ability of Lactobacillus plantarum AC131 have revealed the presence of the mucus adhesion protein (MapA), mucus-binding protein (MUB), and Tu elongation factor (EF-Tu) genes as a genetic determinant of adhesion factors in L. plantarum AC131. MapA is known as a cell surface protein that has an affinity for molecules in the host's gastrointestinal tract [36]. In addition, MUB has been designated as a member of the mucin-binding protein (MucBP) family, which contains proteins that play an important role in the establishment of lactic acid bacteria and host interactions in the gut [51]. EF-Tu was found to be a vital chaperone substrate for hsp33 because heat shock protein might prevent the occurrence of the degradation of oxidative proteins [52].

Based on the RAST annotation in Figure 1, it is known that the probiotic bacteria L. plantarum Dad-13 and L. plantarum Mut-7 have genes that are responsible for the formation of the main components of bacterial cell walls. The Lactobacillus plantarum Dad-13 and L. plantarum Mut-7 bacteria are classified as Gram-positive bacteria. Gram-positive bacteria have different cell wall components from Gram-negative bacteria. Gram-positive bacteria do not have an outer membrane and have a thicker peptidoglycan layer than Gram-negative bacteria. The main components of the cell walls of Gram-positive bacteria include peptidoglycan, polysaccharides, and teichoic acid [53]. According to several previous studies, cell wall components in bacteria play an important role in the attachment of bacteria to host cells. Tables 6 and 7 show the types of genes that play a role in the formation of cell walls of the probiotic bacteria L. plantarum Dad-13 and L. plantarum Mut-7. 
Table 6. Genes related to the cell wall formation of probiotic bacteria L. plantarum Dad-13.

\begin{tabular}{|c|c|c|c|c|}
\hline Category & Subcategory & Subsystem & Role & Abbreviations \\
\hline \multirow{4}{*}{ Cell wall and capsule } & \multirow{4}{*}{$\begin{array}{c}\text { Capsular and } \\
\text { extracellular } \\
\text { polysaccharides }\end{array}$} & \multirow{4}{*}{$\begin{array}{l}\text { Exopolysaccharide } \\
\text { biosynthesis }\end{array}$} & $\begin{array}{l}\text { Transcriptional activator of } \\
\text { exopolysaccharide biosynthesis }\end{array}$ & EpsA \\
\hline & & & $\begin{array}{l}\text { Exopolysaccharide biosynthesis } \\
\text { glycosyltransferase }\end{array}$ & EpsF \\
\hline & & & $\begin{array}{c}\text { Acetyltransferase of } \\
\text { exopolysaccharide biosynthesis }\end{array}$ & EpsH \\
\hline & & & $\begin{array}{l}\text { Capsular polysaccharide synthesis } \\
\text { enzyme }\end{array}$ & $\begin{array}{c}\text { CpsA, CpsB, CpsC, } \\
\text { CpsD, CpsH }\end{array}$ \\
\hline \multirow{3}{*}{ Cell wall and capsule } & \multirow{3}{*}{$\begin{array}{l}\text { Cell wall and } \\
\text { capsule-no } \\
\text { subcategory }\end{array}$} & \multirow{3}{*}{$\begin{array}{l}\text { Peptidoglycan } \\
\text { biosynthesis }\end{array}$} & $\begin{array}{l}\text { Monofunctional biosynthetic } \\
\text { peptidoglycan transglycosylase }\end{array}$ & MG \\
\hline & & & $\begin{array}{l}\text { Cell division protein FtsI } \\
\text { (Peptidoglycan synthetase) }\end{array}$ & FtsI \\
\hline & & & D-alanine ligase & ddlB \\
\hline \multirow[b]{2}{*}{ Cell wall and capsule } & \multirow{2}{*}{$\begin{array}{l}\text { Gram-positive cell wall } \\
\text { components }\end{array}$} & \multirow{2}{*}{$\begin{array}{l}\text { Biosynthesis of teichoic } \\
\text { and lipoteichoic acids }\end{array}$} & Teichoic acid biosynthesis protein & TBP \\
\hline & & & $\begin{array}{l}\text { Regulation of D-alanyl-lipoteichoic } \\
\text { acid biosynthesis }\end{array}$ & DltR, DltS \\
\hline
\end{tabular}

Table 7. Genes related to the cell wall formation of probiotic bacteria L. plantarum Mut-7.

\begin{tabular}{|c|c|c|c|c|}
\hline Category & Subcategory & Subsystem & Role & Abbrev. \\
\hline \multirow{6}{*}{ Cell wall and capsule } & \multirow{6}{*}{$\begin{array}{l}\text { Capsular and } \\
\text { extracellular } \\
\text { polysaccharides }\end{array}$} & \multirow{6}{*}{$\begin{array}{l}\text { Exopolysaccharide } \\
\text { biosynthesis }\end{array}$} & $\begin{array}{c}\text { Transcriptional activator of } \\
\text { exopolysaccharide } \\
\text { biosynthesis }\end{array}$ & EpsA \\
\hline & & & $\begin{array}{l}\text { Exopolysaccharide } \\
\text { biosynthesis } \\
\text { glycosyltransferase }\end{array}$ & EpsF \\
\hline & & & $\begin{array}{l}\text { Acetyltransferase of } \\
\text { exopolysaccharide } \\
\text { biosynthesis }\end{array}$ & EpsH \\
\hline & & & $\begin{array}{l}\text { Capsular polysaccharide } \\
\text { synthesis enzyme }\end{array}$ & $\begin{array}{c}\text { CpsA, CpsB, CpsC, } \\
\text { CpsD, CpsH }\end{array}$ \\
\hline & & & $\begin{array}{l}\text { Capsule polysaccharide } \\
\text { export protein }\end{array}$ & Kps \\
\hline & & & $\begin{array}{l}\text { Glucose-1-phosphate } \\
\text { thymidylyltransferase }\end{array}$ & $\mathrm{RfbA}$ \\
\hline \multirow{3}{*}{ Cell wall and capsule } & \multirow{3}{*}{$\begin{array}{l}\text { Cell wall and } \\
\text { capsule-no } \\
\text { subcategory }\end{array}$} & \multirow{3}{*}{$\begin{array}{l}\text { Peptidoglycan } \\
\text { Biosynthesis }\end{array}$} & $\begin{array}{l}\text { Monofunctional } \\
\text { biosynthetic peptidoglycan } \\
\text { transglycosylase }\end{array}$ & MG \\
\hline & & & $\begin{array}{l}\text { Cell division protein FtsI } \\
\text { (Peptidoglycan synthetase) }\end{array}$ & FtsI \\
\hline & & & D-alanine ligase & ddlB \\
\hline \multirow[b]{2}{*}{ Cell wall and capsule } & \multirow{2}{*}{$\begin{array}{l}\text { Gram-positive cell } \\
\text { wall components }\end{array}$} & \multirow{2}{*}{$\begin{array}{l}\text { Biosynthesis of } \\
\text { teichoic and } \\
\text { lipoteichoic acids }\end{array}$} & $\begin{array}{l}\text { Teichoic acid biosynthesis } \\
\text { protein }\end{array}$ & ТВP \\
\hline & & & $\begin{array}{c}\text { Regulation of } \\
\text { D-alanyl-lipoteichoic acid } \\
\text { biosynthesis }\end{array}$ & DltR, DltS \\
\hline
\end{tabular}

Peptidoglycan is the main component of the cell wall of Gram-positive bacteria [54]. Peptidoglycan is a crosslinked matrix of linear carbohydrate (glycan) chains that are connected to each other through covalent bonds between attached peptides [55]. Peptide bonds consist of a matrix of direct and indirect crosslinked that differ between species. 
Short bonds of one or more amino acids could produce a three-dimensional structure that envelops the cell and functions to maintain the integrity of the bacterial cell wall [54]. Several roles of peptidoglycan in the metabolism of lactic acid bacteria include maintaining resistance to lysozyme, inhibiting autolysis, and acting as a growth factor. The presence of the peptidoglycan $[56,57]$ component in the cell wall of lactic acid bacteria or probiotic bacteria allows it to play an active role in maintaining the immune balance of the gut microbiota in the intestine, and it has a protective role in inflammatory conditions [58]. In addition, one of the components of peptidoglycan —namely, peptidoglycan hydrolase (PGH) - is known to play a role in helping bacteria to survive and live in intestinal epithelial cells through the mechanism of the epidermal growth factor receptor [59].

Teichoic acid is a phosphate-rich cell surface glycopolymer that is widely found in the cell wall components of Gram-positive bacteria [55]. There are two types of teichoic acid: lipoteichoic acid and wall teichoic acid. Lipoteichoic acids adhere to the plasma membrane and stick to the peptidoglycan layer, while teichoic acid from the wall adheres to the peptidoglycan layer and extends to the outside of the bacterial cell wall [53]. Teichoic acid plays a role in protecting cells from cell damage through autolytic activity, cell division, resistance to heat stress, and low osmolarity [60]. In interactions with receptors, teichoic acid is known to act as an intermediary for the attachment of bacterial cells to epithelial and endothelial cells [61]. The presence of teichoic acid and D-alanyl ester affects the interaction of bacteria with various other cell surfaces. A previous study showed that a deficiency of teichoic acid can cause a decrease in the ability of bacterial cells to adhere to host cells. A decrease in attachment ability can increase the negative charge on the surface of bacterial cells, resulting in an increase in repulsion force between the bacterial cell surface and epithelial cells [55,62].

Polysaccharides are one of the components forming the cell walls of Gram-positive bacteria, in addition to peptidoglycan and teichoic acid. Polysaccharides can be classified into three types; (1) exopolysaccharide (EPS), which is present on the surface of microbial cells; (2) capsular polysaccharide (CPS), which is permanently attached to the cell and forms a shield around the bacteria; (3) cell wall polysaccharide (WPS), which covalently or noncovalently binds to the cell wall but does not form a capsule [54]. Polysaccharides in the cell wall contribute to cell division and morphology, act as bacteriophage receptors, offer protection against phagocytosis, and have immunosuppressive functions [63]. Exopolysaccharides found on the surface of bacterial cells play an active role in attachment to the surface of other microorganisms and the formation of biofilms, as well as mediating interactions between other microorganisms and host cells [64].

Cell wall proteins are proteins that are found on the surface of bacterial cells. Approximately $5-10 \%$ of bacterial proteins derived from synthesis in the cytoplasm are released outside of the cytoplasmic membrane [65]. Cell surface proteins facilitate the microbial colonization of the mucosa and survival in the gastrointestinal tract in the process of interaction with host cells. The surface protein found on the cell surface of lactic acid bacteria is the mucus-binding protein (MucBP), which plays an important role in the ability of bacteria to attach to the mucosal layer in intestinal epithelial cells [66].

\section{Conclusions}

Both tested strains of L. plantarum Dad-13 and L. plantarum Mut-7 showed a high cell surface hydrophobicity and a medium autoaggregation capacity. Both strains showed adhesion ability in the colon compartment of the rat intestine, as evidenced by the increasing number of lactic acid bacteria and the low number of E. coli present. Further, Lactobacillus plantarum Dad-13 and L. plantarum Mut-7 featured genes related to adhesion properties that might play important roles in increasing the adherence of probiotics to the intestinal mucosa. Whole-genome sequencing has paved the way to defining genes associated with bacterial adhesion. Future studies are needed to identify the remaining attributes related to genes responsible for adhesion in bacteria. 
Author Contributions: Conceptualization, E.S.R. and A.D.; methodology, A.D.; software, A.D. and P.N.H.; validation, E.S.R. and D.A.S.; formal analysis, A.D. and P.N.H.; investigation, A.D.; resources, A.D.; data curation, A.D. and D.A.S.; writing-original draft preparation, A.D., D.A.S. and E.S.R.; writing-review and editing, A.D., D.A.S. and E.S.R.; visualization, A.D. and P.N.H.; supervision, E.S.R., D.A.S., T.U. and R.W.; project administration, E.S.R.; funding acquisition, E.S.R. All authors have read and agreed to the published version of the manuscript.

Funding: This research was funded by the Ministry of Research and Technology/National Agency for Research and Innovation (RISTEK-BRIN) through the Higher Education of Research and Development research scheme (PPUPT) with the contract number 2164/UN1/DITLIT/DIT-LIT/PT/2021 as well as the Center of Excellence for Research and Application on Integrated Probiotic Industry, Universitas Gadjah Mada, with the contract numbers 1256/E3/PKS.04/KL/2021 and 1078/UN1.P.III/DIT$\mathrm{LIT} / \mathrm{PT} / 2021$.

Institutional Review Board Statement: Not applicable since the intestine material provided by third party.

Informed Consent Statement: Not applicable.

Data Availability Statement: All data presented in this study are available in the article.

Conflicts of Interest: The authors declare no conflict of interest.

\section{References}

1. FAO/WHO. Joint Working Group on Drafting Guideline for The Evaluation of Probiotics in Food. April-May. 2002. Available online: https://www.who.int/foodsafety/fs_management/en/probiotic_guidelines.pdf (accessed on 16 September 2021).

2. Granato, D.; Branco, G.F.; Cruz, A.G.; Faria, J.d.A.F.; Shah, N.P. Probiotic dairy products as functional foods. Compr. Rev. Food Sci. Food Saf. 2010, 9, 455-470. [CrossRef]

3. Ouwehand, A.C.; Salminen, S.; Isolauri, E. Probiotics: An overview of beneficial effects. Lact. Acid Bact. 2002, 82, $279-289$.

4. Rhee, S.J.; Lee, J.-E.; Lee, C.-H. Importance of lactic acid bacteria in Asian fermented foods. Microb. Cell Factories 2011, 10, S5. [CrossRef]

5. Casey, P.G.; Casey, G.D.; Gardiner, G.E.; Tangney, M.; Stanton, C.; Ross, R.P.; Fitzgerald, G.F. Isolation and characterization of anti-Salmonella lactic acid bacteria from the porcine gastrointestinal tract. Lett. Appl. Microbiol. 2004, 39, 431-438. [CrossRef] [PubMed]

6. Okochi, M.; Sugita, T.; Asai, Y.; Tanaka, M.; Honda, H. Screening of peptides associated with adhesion and aggregation of Lactobacillus rhamnosus GG in vitro. Biochem. Eng. J. 2017, 128, 178-185. [CrossRef]

7. Monteagudo-Mera, A.; Rastall, R.A.; Gibson, G.R.; Charalampopoulos, D.; Chatzifragkou, A. Adhesion mechanisms mediated by probiotics and prebiotics and their potential impact on human health. Appl. Microbiol. Biotechnol. 2019, 103, 6463-6472. [CrossRef]

8. Morelli, L.; Callegari, M.L. Taxononomy and biology of probiotics. In Probiotics in Food Safety and Human Health; Goktepe, I., Juneja, V.K., Ahmedna, M., Eds.; Taylor and Francis: Boca Raton, FL, USA, 2006; pp. 67-89.

9. Deepika, G.; Charalampopoulos, D. Chapter 4-Surface and Adhesion Properties of Lactobacilli. In Advances in Applied Microbiology, 1st ed.; Elsevier Inc.: Amsterdam, The Netherlands, 2010; Volume 70.

10. Del Re, B.; Sgorbati, B.; Miglioli, M.; Palenzona, D. Adhesion, auto-aggregation, and hydrophobicity of 13 strains of Bifidobacterium longum. Lett. Appl. Microbiol. 2000, 31, 438-442. [CrossRef] [PubMed]

11. Saxami, G.; Ypsilantis, P.; Sidira, M.; Simopoulos, C.; Kourkoutas, Y.; Galanis, A. Distinct adhesion of probiotic strain Lactobacillus casei ATCC 393 to rat intestinal mucosa. Anaerobe 2012, 18, 417-420. [CrossRef]

12. García-Cayuela, T.; Korany, A.M.; Bustos, I.; de Cadiñanos, L.P.G.; Requena, T.; Peláez, C.; Martínez-Cuesta, M.C. Adhesion abilities of dairy Lactobacillus plantarum strains showing an aggregation phenotype. Food Res. Int. 2014, 57, 44-50. [CrossRef]

13. Collado, M.C.; Meriluoto, J.; Salminen, S. Measurement of aggregation properties between probiotics and pathogens: In vitro evaluation of different methods. J. Microbiol. Methods 2007, 71, 71-74. [CrossRef]

14. Vlková, E.; Rada, V.; Šmehilová, M.; Killer, J. Auto-aggregation and Co-aggregation ability in bifidobacteria and clostridia. Folia Microbiol. 2008, 53, 263-269. [CrossRef] [PubMed]

15. Ferreira, C.L.; Grześkowiak, Ł.; Collado, M.C.; Salminen, S. In Vitro Evaluation of Lactobacillus gasseri Strains of Infant Origin on Adhesion and Aggregation of Specific Pathogens. J. Food Prot. 2011, 74, 1482-1487. [CrossRef] [PubMed]

16. Chen, X.; Tian, F.; Liu, X.; Zhao, J.; Zhang, H.-P.; Chen, W.; Zhang, H. In vitro screening of lactobacilli with antagonistic activity against Helicobacter pylori from traditionally fermented foods. J. Dairy Sci. 2010, 93, 5627-5634. [CrossRef] [PubMed]

17. Nikolic, M.; Jovcic, B.; Kojic, M.; Topisirovic, L. Surface properties of Lactobacillus and Leuconostoc isolates from homemade cheeses showing auto-aggregation ability. Eur. Food Res. Technol. 2010, 231, 925-931. [CrossRef]

18. Panjaitan, R.; Nuraida, L.; Dewanti-Hariyadi, R. Seleksi Isolat Bakteri Asam Laktat Asal Tempe Dan Tape Sebagai Kandidat Probiotik. J. Teknol. Ind. Pangan 2018, 29, 175-184. [CrossRef] 
19. Krausova, G.; Hyrslova, I.; Hynstova, I. In Vitro Evaluation of Adhesion Capacity, Hydrophobicity, and Auto-Aggregation of Newly Isolated Potential Probiotic Strains. Fermentation 2019, 5, 100. [CrossRef]

20. Nuraida, L.; Anggraeni, D.; dan Haryadi-Dewanti, R. Adherence properties of lactic acid bacteria as probiotic candidates isolated from breast milk. Asian J. Food Agro-Ind. 2012, 5, 500511.

21. Tuo, Y.; Yu, H.; Ai, L.; Wu, Z.; Guo, B.; Chen, W. Aggregation and adhesion properties of 22 Lactobacillus strains. J. Dairy Sci. 2013, 96, 4252-4257. [CrossRef]

22. Rahman, M.; Kim, W.S.; Kumura, H.; Shimazaki, K. Auto-aggregation and surface hydrophobicity of bifidobacteria. World J. Microb. Biotechnol. 2008, 24, 1593-1598. [CrossRef]

23. Pan, M.; Kumaree, K.K.; Shah, N.P. Physiological Changes of Surface Membrane in Lactobacillus with Prebiotics. J. Food Sci. 2017, 82, 744-750. [CrossRef]

24. Rahayu, E.S.; Yogeswara, A.; Mariyatun, W.L.; Utami, T.; Watanabe, K. Molecular characteristics of indigenous probiotic strains from Indonesia. Int. J. Probiotics Prebiotics 2015, 11, 109-116.

25. Lavilla-lerma, L.; Pérez-pulido, R.; Martínez-bueno, M.; Maqueda, M.; Valdivia, E. Microbiology Characterization of functional, safety, and gut survival related characteristics of Lactobacillus strains isolated from farmhouse goat's milk cheeses. Int. J. Food Microbiol. 2013, 163, 136-145. [CrossRef] [PubMed]

26. De Souza, B.M.S.; Borgonovi, T.F.; Casarotti, S.N.; Todorov, S.D.; Penna, A.L.B. Lactobacillus casei and Lactobacillus fermentum Strains Isolated from Mozzarella Cheese: Probiotic Potential, Safety, Acidifying Kinetic Parameters and Viability under Gastrointestinal Tract Conditions. Probiotics Antimicrob. Proteins 2018, 11, 382-396. [CrossRef] [PubMed]

27. Gomaa, E.Z. Antimicrobial and anti-adhesive properties of biosurfactant produced by lactobacilli isolates, biofilm formation and aggregation ability. J. Gen. Appl. Microbiol. 2013, 59, 425-436. [CrossRef]

28. Yadav, R.; Puniya, A.K.; Shukla, P. Probiotic Properties of Lactobacillus plantarum RYPR1 from an Indigenous Fermented Beverage Raabadi. Front. Microbiol. 2016, 7, 1683. [CrossRef]

29. Handa, S.; Sharma, N. In vitro study of probiotic properties of Lactobacillus plantarum F22 isolated from chhang-A traditional fermented beverage of Himachal Pradesh, India. J. Genet. Eng. Biotechnol. 2016, 14, 91-97. [CrossRef]

30. Shakirova, L.; Grube, M.; Gavare, M.; Auzina, L.; Zikmanis, P. Lactobacillus acidophilus La5 and Bifidobacterium lacis Bb12 cell surface hydrophobicity and survival of the cells under adverse environmental conditions. J. Nutr. 2013, 40, 85-93.

31. Wu, Q.; Shah, N.P. Effects of Elaidic Acid, a Predominant Industrial Trans Fatty Acid, on Bacterial Growth and Cell Surface Hydrophobicity of Lactobacilli. J. Food Sci. 2014, 79, M2485-M2490. [CrossRef]

32. Wang, B.; Li, J.; Li, Q.; Zhang, H.; Li, N. Isolation of adhesive strains and evaluation of the colonization and immune response by Lactobacillus plantarum L2 in the rat gastrointestinal tract. Int. J. Food Microbiol. 2009, 132, 59-66. [CrossRef]

33. Mantzourani, I.; Chondrou, P.; Bontsidis, C.; Karolidou, K.; Terpou, A.; Alexopoulos, A.; Bezirtzoglou, E.; Galanis, A.; Plessas, S. Assessment of the probiotic potential of lactic acid bacteria isolated from kefir grains: Evaluation of adhesion and antiproliferative properties in in vitro experimental systems. Ann. Microbiol. 2019, 69, 751-763. [CrossRef]

34. Ouwehand, A.C.; Salminen, S. In vitro Adhesion Assays for Probiotics and their in vivo Relevance: A Review. Microb. Ecol. Health Dis. 2003, 15, 175-184.

35. Swidsinski, A.; Loening-Baucke, V.; Theissig, F.; Engelhardt, H.; Bengmark, S.; Koch, S.; Lochs, H.; Dörffel, Y. Comparative study of the intestinal mucus barrier in normal and inflamed colon. Gut 2007, 56, 343-350. [CrossRef]

36. Van Tassell, M.L.; Miller, M.J. Lactobacillus adhesion to mucus. Nutrients 2011, 3, 613-636. [CrossRef] [PubMed]

37. Vinderola, C.G.; Medici, M.; Perdigon, G. Relationship between interaction sites in the gut, hydrophobicity, mucosal immunomodulating capacities and cell wall protein profiles in indigenous and exogenous bacteria. J. Appl. Microbiol. 2004, 96, 230-243. [CrossRef] [PubMed]

38. Muñoz-Provencio, D.; Llopis, M.; Antolín, M.; de Torres, I.; Guarner, F.; Pérez-Martínez, G.; Monedero, V. Adhesion properties of Lactobacillus casei strains to resected intestinal fragments and components of the extracellular matrix. Arch. Microbiol. 2009, 191, 153-161. [CrossRef]

39. Ramos, C.L.; Thorsen, L.; Schwan, R.F.; Jespersen, L. Strain-specific probiotics properties of Lactobacillus fermentum, Lactobacillus plantarum and Lactobacillus brevis isolates from Brazilian food products. Food Microbiol. 2013, 36, 22-29. [CrossRef]

40. Tokatl, M.; Gülgör, G.; Bağder Elmac, S.; Arslankoz Işleyen, N.; Özçelik, F. In Vitro Properties of Potential Probiotic Indigenous Lactic Acid Bacteria Originating from Traditional Pickles. BioMed Res. Int. 2015, 2015, 315819. [CrossRef]

41. Massey, R.C.; Kantzanou, M.N.; Fowler, T.; Day, N.P.J.; Schofield, K.; Wann, E.R.; Berendt, A.R.; Hook, M.; Peacock, S.J. Fibronectinbinding protein A of Staphylococcis aureus has multiple, substituting, binding regions that mediate adherence to fibronectin and invasion to endothelial cells. Cell. Microbiol. 2001, 12, 839-851. [CrossRef]

42. Hymes, J.P.; Klaenhammer, T.R. Stuck in the Middle: Fibronectin-Binding Proteins in Gram-Positive Bacteria. Front. Microbiol. 2016, 7, 1504. [CrossRef]

43. Sarkar, S. A Mini Review on Heat Shock Proteins (Hsps): Special Emphasis on Heat Shock Protein 70 (Hsp70). Brojendra Nath Seal J. Sci. 2017, 70, 130-139.

44. Segal, N.; Shapira, M. HSP33 in eukaryotes-An evolutionary tale of a chaperone adapted to photosynthetic organisms. Plant J. 2015, 82, 850-860. [CrossRef] [PubMed] 
45. Krewing, M.; Stepanek, J.J.; Cremers, C.; Lackmann, J.-W.; Schubert, B.; Müller, A.; Awakowicz, P.; Leichert, L.I.O.; Jakob, U.; Bandow, J.E. The molecular chaperone Hsp33 is activated by atmospheric-pressure plasma protecting proteins from aggregation. J. R. Soc. Interface 2019, 16, 20180966. [CrossRef] [PubMed]

46. Ghazaei, C. Role and mechanism of the Hsp70 molecular chaperone machines in bacterial pathogens. J. Med. Microbiol. 2017, 66, 259-265. [CrossRef] [PubMed]

47. Sikora, A.; Grzesiuk, E. Heat shock response in gastrointestinal tract. J. Physiol. Pharmacol. 2007, 58, 43-62.

48. Rahayu, E.S.; Rusdan, I.H.; Athennia, A.; Kamil, R.Z.; Pramesi, P.C.; Marsono, Y.; Widada, J. Safety Assessment of Indigenous Probiotic Strain Lactobacillus plantarum Dad-13 Isolated from Dadih Using Sprague Dawley Rats as a Model. Am. J. Pharmacol. Toxicol. 2019, 14, 38-47. [CrossRef]

49. Ikhsani, A.Y.; Riftyan, E.; Safitri, R.A.; Marsono, Y.; Utami, T.; Widada, J.; Rahayu, E.S. Safety Assessment of Indigenous Probiotic Strain Lactobacillus plantarum Mut-7 Using Sprague Dawley Rats as a Model. Am. J. Pharmacol. Toxicol. 2020, 15, 7-16. [CrossRef]

50. Tropcheva, R.; Georgieva, R.; Danova, S. Adhesion Ability of Lactobacillus Plantarum AC131. Biotechnol. Biotechnol. Equip. 2011, 25, 121-124. [CrossRef]

51. Dam, T.K.; Brewer, C.F. Multivalent Lectin-Carbohydrate Interactions: Energetics and Mechanisms of Binding. In Advances in Carbohydrate Chemistry and Biochemistry, 1st ed.; Elsevier Inc.: Amsterdam, The Netherlands, 2010; Volume 63.

52. Wholey, W.-Y.; Jakob, U. Hsp33 confers bleach resistance by protecting elongation factor Tu against oxidative degradation in Vibrio cholerae. Mol. Microbiol. 2012, 83, 981-991. [CrossRef]

53. Swoboda, J.G.; Campbell, J.; Meredith, T.C.; Walker, S. Wall Teichoic Acid Function, Biosynthesis, and Inhibition. ChemBioChem 2010, 11, 35-45. [CrossRef]

54. Chapot-Chartier, M.-P.; Kulakauskas, S. Cell wall structure and function in lactic acid bacteria. Microb. Cell Factories 2014, 13, S9. [CrossRef]

55. Brown, S.; Maria, J.P.S.; Walker, S. Wall Teichoic Acids of Gram-Positive Bacteria. Annu. Rev. Microbiol. 2013, 67, 313-336. [CrossRef]

56. Bernard, E.; Rolain, T.; Courtin, P.; Hols, P.; Chapot-Chartier, M.P. Identification of the amidotransferase AsnB1 as being responsible for meso- diaminopimelic acid amidation in Lactobacillus plantarum peptidoglycan. J. Bacteriol. 2011, 193, 6323-6330 [CrossRef]

57. Veiga, P.; Erkelenz, M.; Bernard, E.; Courtin, P.; Kulakauskas, S.; Chapot-Chartier, M.P. Identification of the asparagine synthase responsible for D-Asp amidation in the Lactococcus lactis peptidoglycan interpeptide crossbridge. J. Bacteriol. 2009, 191, $3752-3757$. [CrossRef]

58. Macho Fernandez, E.; Valenti, V.; Rockel, C.; Hermann, C.; Pot, B.; Boneca, I.G.; Grangette, C. Anti-inflammatory capacity of selected lactobacilli in experimental colitis is driven by NOD2-mediated recognition of a specific peptidoglycan-derived muropeptide. Gut 2011, 60, 1050-1059. [CrossRef]

59. Yan, F.; Cao, H.; Cover, T.L.; Washington, M.K.; Shi, Y.; Liu, L.; Chaturvedi, R.; Peek, R.M.; Wilson, K.T.; Polk, D.B. 2011. Colonspecific delivery of a probiotic-derived soluble protein ameliorates intestinal inflammation in mice through an EGFR-dependent mechanism. J. Clin. Investig. 2011, 121, 2242-2253. [CrossRef]

60. Xia, G.; Kohler, T.; Peschel, A. The wall teichoic acid and lipoteichoic acid polymers of Staphylococcus aureus. Int. J. Med. Microbiol. 2010, 300, 148-154. [CrossRef]

61. Weidenmaier, C.; Peschel, A. Teichoic acids and related cell-wall glycopo- lymers in Gram-positive physiology and host interactions. Nat. Rev. Microbiol. 2008, 6, 276-287. [CrossRef]

62. Gross, M.; Cramton, S.E.; Götz, F.; Peschel, A. Key role of teichoic acid net charge in Staphylococcus aureus colonization of artificial surfaces. Infect. Immun. 2001, 69, 3423-3426. [CrossRef] [PubMed]

63. Chapot-Chartier, M.-P.; Vinogradov, E.; Sadovskaya, I.; Andre, G.; Mistou, M.-Y.; Trieu-Cuot, P.; Furlan, S.; Bidnenko, E.; Courtin, P.; Péchoux, C.; et al. Cell Surface of Lactococcus lactis Is Covered by a Protective Polysaccharide Pellicle. J. Biol. Chem. 2010, 285, 10464-10471. [CrossRef] [PubMed]

64. Lebeer, S.; Verhoeven, T.L.A.; Francius, G.; Schoofs, G.; Lambrichts, I.; Dufrêne, Y.; Vanderleyden, J.; De Keersmaecker, S.C.J. Identification of a Gene Cluster for the Biosynthesis of a Long, Galactose-Rich Exopolysaccharide in Lactobacillus rhamnosus GG and Functional Analysis of the Priming Glycosyltransferase. Appl. Environ. Microbiol. 2009, 75, 3554-3563. [CrossRef] [PubMed]

65. Zhou, M.; Theunissen, D.; Wels, M.; Siezen, R.J. LAB-Secretome: A genome-scale comparative analysis of the predicted extracellular and surface- associated proteins of Lactic Acid Bacteria. BMC Genom. 2010, 11, 651. [CrossRef] [PubMed]

66. Boekhorst, J.; Helmer, Q.; Kleerebezem, M.; Siezen, R.J. Comparative analysis of proteins with a mucus-binding domain found exclusively in lactic acid bacteria. Microbiology 2006, 152, 273-280. [CrossRef] [PubMed] 